\title{
Pengajaran Penerjemahan \\ dalam Kelas Penulisan Akademis (Academic Writing) \\ di Universitas Multimedia Nusantara
}

\author{
Niknik M. Kuntarto \\ Universitas Multimedia Nusantara \\ Email:niknik@umn.ac.id
}

\begin{abstract}
As information and communication technology grows wider and more influential in shaping the training of translators recently, the needs to reformulate translator's competences are also increasing. By combining some necessary traits and characteristics of good translators coming from the field of linguistics with critical pedagogy fostered in Academic Writing course, the author will argue that translation teaching within the framework of Academic Writing class, yields creativity and more promises on the spirit of keeping humanization alive which is at the same time challenged by the ascent notion of machine translation. The growing dependence on using google translate, for most of the students observed in this case study, highlights the importance to embrace both familiarity with the logic and limitation of MT as well as rootedness within the discourse which empowers human autonomy, thus didactic translation. In this respect, the lecturer plays dual role in becoming role-model for students in translation as well as critical evaluator for their imperfect results of translating text on plagiarism seen from the linguistic phenomenon.
\end{abstract}

Keywords: translation, translation competence, didactic translation, technology-based translation

\section{Intisari}

Seiring perkembangan teknologi informasi dan komunikasi yang semakin luas dan semakin berpengaruh dalam membentuk pelatihan para penerjemah baru-baru ini, kebutuhan untuk merumuskan kembali kompetensi penerjemah juga meningkat. Dengan menggabungkan beberapa ciri dan karakteristik penerjemah baik yang berasal dari bidang linguistik dengan pedagogi kritis yang dipupuk dalam kursus Penulisan Akademik, penulis akan berpendapat bahwa pengajaran terjemahan dalam kerangka kelas Penulisan Akademik, menghasilkan kreativitas dan lebih banyak janji pada semangat menjaga humanisasi hidup yang pada saat bersamaan ditantang oleh konsep pendakian mesin terjemahan. Ketergantungan yang berkembang pada penggunaan google translate, bagi sebagian besar siswa yang diamati dalam studi kasus ini, menyoroti pentingnya merangkul baik keakraban dengan logika dan keterbatasan MT serta berakar dalam wacana yang memberdayakan otonomi manusia, sehingga terjemahan didaktik. Dalam hal ini, dosen memainkan peran ganda untuk menjadi teladan bagi siswa dalam terjemahan serta evaluator kritis untuk hasil terjemahan teks plagiarisme yang tidak tepat yang dilihat dari fenomena linguistik.

Kata kunci: terjemahan, kompetensi penerjemahan, terjemahan didaktik, terjemahan berbasis teknologi 


\section{Pendahuluan}

Kebutuhan di bidang penerjemahan semakin meningkat seiring pesatnya perkembangan ilmu pengetahuan dan teknologi informasi pada era globalisasi sekarang. Tidak sedikit isu menyangkut batas-batas negara, baik secara geografis maupun virtual, ketahanan nasional, ideologi kebangsaan, maupun peraturan perundang-undangan lintas negara, yang dapat dilacak asal-muasal permasalahannya pada ketimpangan berbahasa dan kurang memadainya penerjemahan. Gejala pertarungan antargugus identitas dan subidentitas untuk memperebutkan pengaruh dalam ruang publik dewasa ini juga bisa dilihat sebagai tarik-menarik berbagai arus translasi dan interpretasi makna atas konsepkonsep kunci yang dipertaruhkan dan diperjuangkan supaya menjadi isu arus utama (mainstream). Peran sentral bahasa dan penerjemahan untuk mengurai berbagai persoalan di atas sudah tidak diragukan lagi, tetapi bagaimana keterampilan penerjemahan itu dilatihkan dalam ruang-ruang yang lebih kecil dan terbatas, misalnya di dalam ruang kelas, masih belum banyak diulas oleh para pakar sosio-linguistik maupun pedagogik. Hal ini masih belum ditambahi fakta bahwa berlebihannya informasi di Era Informasi dewasa ini, terutama kluster informasi yang luput disaring dan dikritisi, tidak jarang membuat para pengambil keputusan mengalami gejala information overload (Hurst, 2007: 5-8; Kovach \& Rosenstiel, 2010: 6-8), yang menghambat kinerja mereka.

Dalam konteks dan tantangan riil semacam inilah baik pembelajaran tentang penerjemahan di satu sisi, maupun berpikir kritis dalam penulisan akademis, di sisi lain, mendapatkan relevansi akutnya. Untuk menghasilkan calon pemimpin (para pengambil keputusan dan pembuat kebijakan) masa depan yang bukan hanya cerdas-rasional, melainkan juga tanggap-empatik terhadap perubahan dinamika ekonomi, sosial, politik, budaya dan kebahasaan, penulis berkeyakinan bahwa itu semua dapat dimulai sejak bangku kuliah. Mengapa demikian? Para mahasiswa sebagai orang muda terpelajar, adalah masa depan bangsa, di mana pun mereka berada dan apa pun bidang keilmuan yang mereka pilih untuk tekuni. Memandu orang muda untuk menyiapkan masa depan mereka, salah satunya lewat perkuliahan, berarti sekaligus membuka jalan untuk menaikkan tingkat peradaban bangsa dan negeri.

Ikhtiar memadukan materi kuliah 'pengajaran dan pembelajaran tentang penerjemahan' dengan tugas sebagai dosen yang mengajar Mata Kuliah Penulisan Akademis (Academic Writing) untuk para mahasiswa Jurusan Ilmu Komunikasi di 
Universitas Multimedia Nusantara selama Semester Genap 2015-2016 menjadi latar pengalaman yang dianggap cukup memadai oleh penulis untuk menuliskan analisis ini. Kerja sama yang telah ditunjukkan para mahasiswa untuk menjadi mitra belajar tentang penerjemahan sekaligus belajar menulis ragam akademis sungguh memberikan kesan yang mendalam---yang refleksi dan evaluasi tentangnya penulis sampaikan dalam makalah terbatas ini.

Penerjemahan sebagai Proses Mempertinggi Kesadaran Berbahasa Para Peserta Didik Bagian makalah ini bertolak dari pertanyaan "sejauh mana penerjemahan dapat menjadi alat yang sah dan efektif dalam belajar bahasa asing?” (Dagilienè, 2012: 124). Untuk menjawab pertanyaan besar ini, pantas diperhatikan konsep kuncinya yaitu penerjemahan pedagogis.

Penerjemahan pedagogis berangkat dari asumsi dasar bahwa praktik penerjemahan sebagai metode pembelajaran bahasa, terutama bahasa asing, bukan sekadar "transfer linguistik makna dari satu bahasa ke bahasa lain" atau "kegiatan yang tidak komunikatif yang tidak sesuai dengan kebutuhan umum belajar bahasa...[penerjemahan itu] menghabiskan waktu, membosankan, dan tidak relevan" (Dagiliene, 2012 dalam Emzir, 2015: 217), melainkan suatu cara untuk memperkaya kompetensi peserta didik. Pengembangan kemampuan peserta didik untuk berkomunikasi dalam bahasa target (BT) merupakan tujuan keberadaan pengajaran bahasa asing, maka, penerjemahan pedagogis dipercaya dapat menjadi alat yang sangat bermanfaat untuk mencapai tujuan tersebut.

Jika kesadaran berbahasa peserta didik diibaratkan sebagai cakrawala mengadanya, penerjemahan dapat dilihat sebagai upaya untuk memperluas cakrawala tersebut. Jika cakrawala mengada si penutur bahasa tersebut menjadi lebih luas, dunianya pun juga akan bertambah besar. Seperti pernah disampaikan seorang filsuf Bahasa terkemuka abad ke-20, Ludwig Wittgenstein (1889-1951), dalam adikaryanya, Tractatus Logico-Philosophicus (1922: 5.6), "batas-batas dari bahasaku berarti batasbatas dari duniaku." (aslinya dinyatakan dalam bahasa Jerman sebagai "Die Grenzen meiner Sprache bedeuten die Grenzen meiner Welt.")

Penerjemahan yang baik haruslah mengalir secara alami, menciptakan kembali baik gaya dan konteks dari teks asli, maupun mengikuti konvensi bahasa target. Penerjemahan bukanlah aktivitas beku dan mengisolasi peserta didik dari keseharian 
hidupnya. Penerjemahan justru merupakan kegiatan komunikatif yang melibatkan komunikasi intens antara guru dengan peserta didik. Tugas penerjemahan dapat menjadi pintu masuk yang tepercaya untuk membahas baik isu bahasa secara mikro maupun dunia kehidupan secara makro. Keterampilan berbicara maupun menyimak dapat ditingkatkan dengan melibatkan peserta didik dalam penerjemahan.

Merujuk pada pandangan Newmark (1988: 6) tentang penerjemahan, tidak ada hal yang disebut 'terjemahan yang sempurna, ideal, atau 'tepat sekali'" mengingat bahwa seorang 'penerjemah yang baik tidak pernah puas dengan hasil terjemahannya...ia (penerjemah) selalu berusaha memperluas pengetahuannya dan meningkatkan cara-cara mengekspresikan (teks yang ia terjemahkan)... (dalam penerjemahan) ia bekerja sekaligus pada empat tingkat: sains, kecakapan, seni, dan selera." Dari kategorisasi yang dibuat Newmark ini, tidaklah sulit untuk menyimpulkan bahwa fungsi pedagogis penerjemahan tidak bisa dilepaskan dari tuntutan profesionalismenya.

Alan Duff (dalam Emzir, 2015: 224) menyoroti sekurang-kurangnya lima alasan untuk menggunakan terjemahan dalam ruang kelas (jadi, 'pengajaran penerjemahan'), yaitu (a) pengaruh bahasa ibu, (b) kealamiahan kegiatan, (c) (pelatihan) Aspek keterampilan, (d) (perluasan) Realitas bahasa, dan (e) kegunaan (pedagogis). Dengan sendirinya, keberadaan kelima alasan di atas semakin memperkuat argumen bahwa penerjemahan merupakan proses untuk mempertinggi kesadaran bahasa para peserta didik, sesuatu yang 'niscaya dibutuhkan' bukan hanya oleh para individu pembelajar, melainkan juga oleh khalayak pengguna hasil terjemahan mereka.

Jika pandangan-pandangan di atas dapat dirangkum dan disimpulkan, penulis cenderung memilih kesimpulan versi Leonardi (2011: 25-26), yang mengatakan,

Penerjemahan memungkinkan adanya pemindahan gugus kecakapan bahasa dari satu bahasa ke lainnya. Selain itu, kemampuan kognitif yang diperoleh ketika mempelajari sebuah bahasa (L1) dapat digunakan dalam akuisisi dan profisiensi bahasa-bahasa lainnya (L2), dan sebaliknya. Dalam terang inilah penerjemahan menjadi sebuah alat pengajaran bilingual yang efektif untuk melengkapi (gugus keterampilan belajar bahasa) seperti membaca, menulis, mendengarkan dan berbicara. Penerjemahan tidak dapat dihindari ketika para siswa belajar bahasa asing karena mereka menerjemahkan ke dalam dan ke luar dari bahasa yang mereka kuasai (L1). 
Setelah didahului kerangka teori penerjemahan yang relatif memadai, tiba gilirannya penulis mengaplikasikan berbagai teori dan pandangan tersebut dalam studi kasus yang lebih terukur, yaitu latihan penerjemahan dalam ruang kelas berikut ini.

\section{Tahap-tahap Pelatihan Penerjemahan dalam Ruang Kelas Penulisan Akademis}

Garding-Salas (2000) dalam Emzir (2015 mengemukakan prosedur atau langkahlangkah kegiatan latihan penerjemahan di kelas yang menempatkan mahasiswa sebagai peran sentral, sementara dosen berfungsi sebagai fasilitator.

Pelatihan penerjemahan ini meliputi tiga tahap utama, yaitu 1) Kegiatan Awal, 2) Kegiatan Inti, dan 3) Evaluasi. Berikut disampaikan secara terperinci gugus kegiatan tersebut, pertama-tama dengan menegaskan langkah-langkah prinsipilnya, kemudian dikonkretkan dengan aplikasinya, sesuai teks spesifik yang dirujuk:

Kegiatan awal terdiri dari lima tahap, yaitu sebagai berikut.

(1) Pada tahap ini dosen memilih teks yang akan diterjemahkan dengan mempertimbangkan berbagai aspek seperti tingkat kesulitan, topik, atau ranah keilmuan. Dalam studi kasus ini, dosen memilih Bab 1, Plagiarism: Why the Need for a Linguistic Analysis? yang diambil dari buku karya Diane Pecorari (2008) berjudul Academic Writing and Plagiarism: A linguistic analysis, hlm. 1-7. Salah satu topik bahan ajar dalam Mata Kuliah Penulisan Akademis adalah soal cara-cara menghindari Plagiarisme (Kuntarto dan Putranto, 2015: 227-231) sehingga pilihan bab dan buku ini dapat dibenarkan dalam konteks Pelatihan Penerjemahan. Tingkat kesulitan bahasa Inggris sebagai BS dalam buku ini, menurut pandangan dan pertimbangan dosen, termasuk tingkat Menengah sampai Mahir (Intermediate up to Advanced Level).

(2) Pembacaan teks secara cepat: mahasiswa diminta membaca teks tersebut dengan cepat untuk melakukan identifikasi sumber, norma, jenis teks, register, gaya, dan pembaca teks yang dipilih. Pembacaan teks terpilih secara bersama-sama dilakukan selama 50 menit pertama waktu perkuliahan, pada Tatap Muka ke-12. Identifikasi sumber meliputi profil pengarang dan profil buku secara umum. Lewat mesin pencari google, ditemukan fakta bahwa pengarang buku adalah seorang dosen tetap bergelar Profesor pada jurusan Bahasa di Linnaeus University, Swedia. Juga ditemukan informasi bahwa buku tersebut memang ditulis dalam bahasa Inggris, 
meskipun sang pengarang buku bukan orang kelahiran atau warganegara Inggris. Jenis teksnya adalah buku teks untuk keperluan akademis (belajar-mengajar), normanya adalah norma bahasa standar, registernya adalah formal, gaya bahasanya adalah akademis (academese), sementara pembaca teks yang dipilih (sebagai target pembaca dan pemaham teks terjemahan) adalah para mahasiswa peserta perkuliahan Penulisan Akademis itu sendiri.

(3) Imajinasi dan penentuan klien (target pembaca) serta kebutuhan-kebutuhan mereka. Imajinasi di sini maksudnya latihan membayangkan seperti apa profil pembaca yang akan membaca hasil terjemahan. Juga dibayangkan tingkat pemahaman linguistik mereka. Secara umum dicapai kesepakatan bahwa tingkat berbahasa Inggris (BS) seorang mahasiswa Ilmu Komunikasi UMN tahun kedua adalah dasar sampai menengah, sedangkan tingkat berbahasa Indonesianya adalah menengah sampai mahir. Kebutuhan nyata untuk membantu mahasiswa dalam proses penerjemahan adalah kamus bahasa Inggris-Indonesia versi luring (Modern English - Indonesian Dictionary), terbitan Gramedia Pustaka Utama, 2010, yang disusun oleh drs. Peter Salim, atau kamus bahasa Inggris-Indonesia yang tersedia secara daring (yaitu google translate atau sederet.com) sebagai pembandingnya.

(4) Pembacaan teks sumber secara komprehensif dan umum, lalu dilanjutkan dengan membaca secara mendalam: Kegiatan ini bertujuan untuk menekankan pada permasalahan penerjemahan yang akan muncul. Mengingat keterbatasan waktu (2 SKS atau 100 menit setiap Tatap Muka di kelas) untuk membaca keseluruhan sumber, maka teks sumber dibaca secara cepat (skimming). Permasalahan penerjemahan yang muncul di awal adalah kesulitan untuk memahami kalimatkalimat yang terbilang cukup panjang dalam bab buku ini (>20 kata).

(5) Pra-sunting dan penilaian kualitas tulisan: Tahap ini penting dilakukan pada bagian awal sehingga kesalahan yang ditemukan dapat segera dikoreksi. Tahap ini dilewati dengan susah-payah dikarenakan tingkat pemahaman bahasa Inggris (norma standar, register formal, dan gaya akademis) para mahasiswa ternyata masih lebih banyak yang berada di tingkat dasar (basiclentry level) daripada menengah (intermediate). Tahap pra-sunting hasil terjemahan mengandaikan para mahasiswa bukan hanya menguasai pengetahuan linguistik dan penerjemahan, tetapi juga pengetahuan budaya dan tekstual (Shreve, 2006: 27-42). Penilaian kualitas tulisan hasil terjemahan mahasiswa juga belum bisa dikatakan cukup memadai serta objektif jika 
dilakukan tanpa bimbingan dan masukan dari dosen pembimbing (hal yang akan diperjelas dalam bagian evaluasi di bawah nanti).

Kegiatan inti terdiri dari sebelas tahap, yaitu sebagai berikut.

1) Pada tahap ini mahasiswa bekerja secara kelompok. Dosen membagi 36 orang mahasiswa ke dalam 4 kelompok besar, setiap kelompok beranggotakan 9 orang. Kelompok dibentuk secara voluntaristik, artinya anggota kelompok ditemukan berdasarkan pilihan mereka sendiri, bukan ditentukan dosen.

2) Dosen membagi teks ke dalam beberapa segmen, lalu setiap mahasiswa mendapat porsi terjemahan yang adil. Teks sepanjang 2263 kata dibagi menjadi empat buah segmen, yang terdiri dari paling sedikit 543 kata dan paling banyak 597 kata.

3) Jika mahasiswa sudah mengenal topik dengan baik, mereka melakukan penerjemahan awal. Pendekatan ini biasanya dilakukan secara lisan. Mahasiswa belum mengenal topik 'plagiarisme' dan 'analisis linguistik' dengan baik sehingga dosen menempuh langkah berikutnya di bawah ini.

4) Sebaliknya jika tidak mengenal topik dengan baik, mereka harus mencari berbagai sumber dokumentasi untuk mencapai pemahaman yang lebih dalam tentang topik yang ditelaah. Sumber dokumentasi lain yang dianggap membantu untuk memahami topik plagiarisme dalam konteks Penulisan Akademis adalah buku teks yang menjadi acuan utama dalam perkuliahan yaitu 99 Cara Mudah Menulis Karya Ilmiah (Indo Publika, 2015) serta dua buah artikel berikut ini, (1) "Menghindari Perangkap Plagiarisme dalam Menghasilkan Karya Tulis Ilmiah" karya Prof. Dr. Ir. H. Zulkarnain, M.Hort.Sc. dari Fakultas Pertanian Universitas Jambi. Artikel bisa diakses di http://webunja.unja.ac.id/artikel/75-prof-dr-ir-h-zulkarnain-mhortsc dan (2) "Plagiarisme, Runtuhnya Tembok Kejujuran Akademik" karya Herqutanto dari Departemen Ilmu Kedokteran Komunitas, Fakultas Kedokteran Universitas Indonesia, Jakarta. Artikel bisa diakses di http://journal.ui.ac.id/index.php/eJKI/article/view/1589/1335

5) Latihan berikutnya adalah mahasiswa melakukan versi kedua terjemahan mereka sendiri dengan membuat draf terjemahan secara tertulis. Draf terjemahan secara tertulis dibuat secara proporsional dengan cara membagi paragraf yang ada dalam setiap segmen untuk setiap anggota kelompok. Untuk menambah tingkat tanggungjawab mahasiswa, bagian yang diterjemahkan dibuat overlapping, untuk 
nantinya dibandingkan oleh ketua kelompok lalu dirangkum menjadi satu. Misalnya, untuk kelompok pertama yang menerjemahkan Segmen 1, mahasiswa A mendapat bagian menerjemahkan kalimat pertama dan kedua dari segmen tersebut, mahasiswa B mendapat bagian menerjemahkan kalimat kedua dan ketiga dari segmen tersebut, begitu seterusnya sampai segmen habis dibagi-bagi.

6) Draf terjemahan secara tertulis dibuat oleh setiap kelompok dengan sorotan pada kata-kata serta kalimat yang sulit untuk dicari padanan kata persisnya dalam bahasa Indonesia, misalnya 'passing off' (Segmen 1, par. 1, baris ke-5 \& 6), 'a linguistic phenomenon' (Segmen 1, par. 1, baris ke-8 \& 9), 'scathing terms' (Segmen 1, par. 2, baris ke-11), 'a common metaphor' (Segmen 1, par. 2, baris ke-15), 'the discourse communities ' (Segmen 1, par. 3, baris ke-17), 'the esteem of science' (Segmen 1, par. 4, baris ke-21), 'cast in moral terms' (Segmen 1, par. 5, baris ke-24\&25), 'other flawed aspects of a text' (Segmen 1, par. 5, baris ke-27), 'an undesirable textual feature' (Segmen 1, par. 6, baris ke-30), 'lexico-grammatical choices' (Segmen 1, par. 6, baris ke-33 \&34), 'a text lacks what would otherwise be a serious flaw' (Segmen 1, par. 6, baris ke-38).

7) Selanjutnya mahasiswa (ditunjuk satu orang mewakili kelompok) akan membacakan hasil terjemahannya, sesuai dengan urutan teks asli (BS). Hasil terjemahan dipresentasikan di depan kelas pada TM berikutnya (TM 13). Setiap kelompok diberi waktu 10-15 menit untuk membacakan hasil terjemahannya, sesuai urutan kelompok dan kronologi teks. Pada saat pembacaan hasil terjemahan, suasana dijaga tetap hening agar pendengar dapat lebih konsentrasi menyimak hasil terjemahan setiap kelompok dan membandingkannya dengan hasil terjemahan kelompok sendiri. Sebagian mahasiswa bahkan merekam paparan presentasi tersebut.

8) Para mahasiswa dan dosen menyimak pembacaan sehingga pada kegiatan tutorial ini terjadi diskusi dan kritik yang bertujuan "membangun sikap" dan melengkapi penerjemahan teks. Setiap selesai sesi pembacaan teks terjemahan oleh setiap kelompok, dosen memberikan masukan untuk pemilihan kata-kata padanan, terutama istilah-istilah kunci atau frasa yang dianggap kunci untuk memahami teks. Maksimal waktu 7 menit untuk pemberian masukan (kritik dan saran) pada setiap kelompok.

9) Para mahasiswa harus mempertahankan pekerjaan mereka terhadap kritik. Mahasiswa (dalam kelompok) diberikan kesempatan untuk mencatat masukan dari 
dosen, dan, setelah dosen tidak lagi menyampaikan masukan, mahasiswa diperkenankan untuk mempertahankan, sejauh rasional dan bisa diterima, hasil terjemahan mereka. Dari empat kelompok yang terlibat membahas keempat segmen teks yang diterjemahkan, kelompok yang mengerjakan Segmen 3 merasa terbantu oleh keberadaan bagan (figure) 'tipe-tipe plagiarisme' untuk memahami dengan lebih baik deskripsi sebelum maupun sesudah bagan sehingga kualitas terjemahan mereka untuk bagian tersebut pun hampir mencapai nilai A (85), dan mereka berani beradu pandangan dengan dosen.

10) Kegiatan metakognitif: Mahasiswa dibantu dosen, menganalisis strategi dan prosedur penerjemahan yang mereka gunakan, dan membahas alasan. Berdasarkan hasil pengamatan dosen terhadap kerja dan kinerja mahasiswa yang diberikan tugas menerjemahkan teks, ternyata mereka lebih banyak (lebih dari $80 \%$ dari total mahasiswa yang ditugaskan atau $>58$ orang) yang mengandalkan terjemahan mesin (machine translation). Dalam hal ini, mereka menggunakan bantuan piranti lunak google translate. Alasan yang mereka ajukan kepada dosen ketika ditanya mengapa menggunakan google translate adalah 1) lebih mudah, 2) lebih cepat, 3) hasil terjemahan lumayan memuaskan.

11) Mahasiswa melakukan revisi dan pos edit. Pekerjaan diketik, spasi ganda, dan diberi halaman sesuai dengan aslinya. Dikerjakan oleh mahasiswa sebagai pekerjaan rumah (PR), dan hasilnya baru dikumpulkan lagi kepada dosen pada TM 14, yaitu tatap muka terakhir sebelum Ujian Akhir Semester (UAS).

Evaluasi terdiri dari tiga tahap.

1) Dosen membuat revisi akhir. Dosen berkonsultasi dengan sejumlah ahli bahasa lain yang ada di kampus UMN untuk menguatkan (koroborasi) pandangan dan evaluasi pilihan kata-kata terjemahan. Dosen membuat panduan penilaian untuk hasil terjemahan mahasiswa, dengan penentuan kriteria yaitu a) kesepadanan, b) akurasi, dan c) rasa atau estetika bahasa (linguistic sense)

2) Dosen memberikan evaluasi formatif dan membuat komentar. Evaluasi formatif disampaikan kepada setiap ketua kelompok secara tertulis dan dikirimkan lewat surat elektronik (selagi mahasiswa masuk dalam Minggu Tenang pra-UAS) 
3) Dosen menekankan temuan-temuan yang bermanfaat dari hasil diskusi dan presentasi kelompo. Ada tiga buah temuan yang digarisbawahi oleh dosen terkait dengan penerjemahan dan hasil terjemahan, yaitu sebagai berikut.

a) Pengetahuan budaya yang dimiliki mahasiswa menyangkut konteks 'dunia akademis Barat' ternyata masih terbilang rendah. Hal ini menyulitkan mereka untuk mengenali asal-usul dan cakupan terma-terma khusus yang ditemukan dalam teks. Juga meskipun mahasiswa tampak berhasil menerjemahkan frasa atau kata yang sulit dalam segmen, contoh, 'linguistic phenomenon' yang diterjemahkan menjadi 'gejala bahasa', ketika ditanya lebih jauh oleh dosen artinya apa, mereka menunjukkan kekurang-tahuan. Juga ketika menerjemahkan 'how the act is cast in moral terms,' sangat sedikit mahasiswa yang memahami benar-benar kaitannya bagian tersebut dengan wacana seputar moralitas (etika).

b) Rendahnya tingkat keakraban (familiarity) terhadap teks yang diterjemahkan, terutama dalam hal formalitas ragam bahasa dan academese juga menjadi kendala mahasiswa ketika menerjemahkan 'kata dalam konteks kalimatnya' dan 'kalimat dalam konteks paragraf yang menaunginya'. Dalam beberapa bagian terjemahan, terasa sekali bahwa kualitas terjemahan mahasiswa, juga ketika sudah memasuki tahapan revisi dan pos edit, masih belum luwes dan belum ‘jalan’ sepenuhnya. Contoh, ketika mahasiswa menerjemahkan kalimat terakhir dari segmen 1, yang berbunyi "The absence of plagiarism does not guarantee that sources have been used effectively, but simply that a text lacks what would otherwise be a serious flaw," yang diterjemahkan menjadi "Tidak adanya plagiarisme tidak menjamin bahwa sumber telah digunakan secara efektif, tetapi hanya bahwa sebuah teks tidak memiliki apa yang sebaliknya akan cacat serius." Kalimat 'sebuah teks tidak memiliki apa yang sebaliknya akan cacat serius' merupakan terjemahan yang kaku dan tidak jalan jika dipahami dengan menggunakan nalar berbahasa Indonesia yang baik dan benar.

c) Ketergantungan mahasiswa yang cukup besar pada terjemahan mesin, dalam hal ini google translate, bisa menjadi sebuah berkat, tetapi jika dievaluasi secara lebih kritis, mendalam, dan berpandangan jauh ke depan---pokok yang akan diulas pada bagian terakhir makalah ini---bisa juga menjadi sebuah kutuk. 


\section{Pengajaran Penerjemahan Berbasis Teknologi: Sebuah Evaluasi}

Topik ini, secara terbatas, dibahas juga dalam buku teks Mata Kuliah Penulisan Akademis (Kuntarto dan Putranto, 2015: 279-280). Dilatarbelakangi oleh kemajuan teknologi informasi secara global terutama ditopang oleh semakin meluasnya penggunaan internet dalam kehidupan sehari-hari dan aplikasi dari sejumlah besar riset seputar kecerdasan buatan (artificial intelligence), terjemahan oleh mesin (selanjutnya disebut MT) juga mengalami baik perluasan penggunaan maupun percepatan tingkat aksesibilitas para pengguna. Gugus kompetensi penerjemahan yang disinggung di bagian awal makalah ini, yang nantinya bermuara pada kompetensi si penerjemah dikarenakan memiliki seperangkat kecakapan (skills) yang disyaratkan, perlu ditinjau kembali dan disusun ulang dengan memasukkan unsur penguasaan teknologi secara umum, kecakapan menelusuri jejaring dan literasi informasi secara daring dalam pelatihan untuk para penerjemah (Raído, 2014: 1-7) serta pemahaman yang memadai akan logika (sekaligus keterbatasan) MT secara khusus (Somers, 2003: 1-29; Wilks, 2009: 1-7; Pym, 2011: 1-7; Aiken dan Balan, 2011: 1-5).

Pada satu sisi, kemajuan teknologi memang secara praktis diakui sangat membantu para calon penerjemah, atau sekurang-kurangnya dalam batasan makalah ini, para mahasiswa yang diperkenalkan pada dinamika penerjemahan teks dalam mata kuliah Penulisan Akademis. Eksistensi MT dalam bentuk google translate, misalnya, jelas-jelas mempermudah tugas menerjemahkan teks dari satu bahasa asing ke dalam bahasa target yang, katakanlah, dua dekade lalu, hanya ditumpukan pada keterampilan siswa untuk mencatat, membolik-balik kamus, mengingat, dan menghaluskan hasil terjemahannya.

Seperti ditandaskan Pym (2012: 12-13), “Karena penerjemahan itu lebih menyangkut mengasah kecakapan alih-alih penambahan pengetahuan, untuk mencapai tingkat 'pakar' dibutuhkan praktik yang diulang-ulang. Atas dasar alasan ini saja, yang namanya TM/MT idealnya harus digunakan sebanyak mungkin dalam proses siswa belajar menerjemahkan, dan bukan hanya disempitkan pada mata kuliah khusus tentang teknologi terjemahan. Dengan mengatakan hal itu, pada tahap perkembangan yang tepat, para siswa sebaiknya didorong untuk menggunakan teknologi yang mereka sukai dan kuasai sebanyak mungkin dan dalam berbagai kuliah yang berbeda-beda. Hal ini berarti: 1) memastikan bahwa mereka memiliki teknologi tersebut dalam komputer jinjing mereka, 2) pengajaran dikondisikan dalam lingkungan yang di dalamnya mereka 
dapat menggunakan komputer jinjing mereka secara daring, dan 3) penggunaan teknologi yang gratis atau terjangkau."

Akan tetapi, tetap perlu diingat di sini bahwa, seiring sejalan dengan perkembangan teknologi dalam hal terjemahan, teks sebagai bahan terjemahan tetap perlu dilihat secara paradigmatik, yaitu upaya mengomunikasikan gagasan antarmanusia yang bergerak dalam linieritas semantik dan kohesi sintagmatis tertentu yang tidak jarang terluput ketika ditangkap oleh jaring-jaring logika MT (Pym, 2011: 3). Dalam kerangka kemajuan teknologi, karya terjemahan kita tidak jarang ditentukan oleh, seperti ditandaskan Pym (2011: 4), "pencarian lewat internet, glossaries, pengoreksi ucapan, pengoreksi gramatika, gugus penyimpan data memori terjemahan maupun terjemahan mesin, dan segala sesuatu lainnya yang menyerupai teknologi komunikasi. Gerakan ketergantungan pada teknologi semacam ini sebenarnya tidak menjauhkan kita dari teks itu sendiri, tetapi dari linieritas. Semakin kita menggunakan teknologi, semakin sulitlah mengambil keputusan-keputusan dalam kerangka keutuhan dan kesinambungan, dan semakin jauhlah kita melihat penerjemahan sebagai proses komunikasi antarmanusia." Jika ini yang terjadi, maksudnya 'ketergantungan pada teknologi,' kemajuan teknologi tidak secara otomatis menjadikan manusia sebagai agen (pelaku perubahan) bahasa yang otonom dan berdaulat, bahkan justru menjauhkan dirinya dari potensi-potensi yang ia miliki untuk mengutuhkan dirinya.

Akhir kata, minat dan perhatian kita pada humanisasi hendaknya tidak dicampuradukkan dengan tilikan kritis yang dapat kita tujukan pada keberadaan teknologi, menyitir pandangan Pym belasan tahun lalu (2004: 183). Secara umum, kita sepakat bahwa penggunaan teknologi adalah unsur kunci dari pemanusiaan manusia (humanisasi). Idealnya, semakin kita menggunakan teknologi, kita menjadi semakin manusiawi, sekaligus mengubah dunia dan relasi-relasi yang ada di dalamnya yang tetap tidak dapat dijangkau oleh yang-bukan manusia. Komunikasi elektronik memang memperluas jangkauan indera kita sekaligus memampukan kita untuk bekerja sama dengan siapa pun tanpa lagi khawatir soal jarak dan waktu yang memisahkan. Yang masih menjadi persoalan terkait dengan teknologi adalah bagaimana kita menggunakannya, bagaimana distribusi sosialnya perlu diatur dan dibatasi, bagaimana agar yang ditayangkan di layar sungguh-sungguh menjadi cerminan dari yang dipikirkan manusia, dan bukan apa itu teknologi pada dirinya sendiri. 
Membatasi akses para siswa terhadap kerja dan kinerja MT dalam proses penerjemahan memang bukan hal bijak yang perlu dilakukan seorang dosen, atau guru bahasa. Akan tetapi, membiarkan para siswa melulu tergantung pada penggunaan MT sebagai satu-satunya rujukan mereka saat mengerjakan tugas terjemahan teks, tanpa diimbangi oleh dorongan dan lecutan keingintahuan yang sistematis tentang latar sosiobudaya, sosio-ekonomi, sosio-politik dan berbagai dimensi lainnya yang berada di balik lahir dan munculnya teks, juga bukan karakteristik seorang dosen yang ideal dalam menumbuhkan kecintaan para siswa akan kemampuan akal budi dan kompetensi pribadi untuk memahami teks asing.

\section{Simpulan dan Rekomendasi}

Dalam makalah singkat ini, penulis sudah berargumen seara sistematis untuk membuktikan bahwa keterampilan penerjemahan dan profesi sebagai penerjemah dalam dunia kerja dewasa ini memang merupakan isu yang krusial untuk ditanggapi lembaga pendidikan yang memiliki perhatian pada kualitas berbahasa para siswa didiknya. Selain berfungsi untuk mempertinggi kesadaran berbahasa pada peserta didik, penerjemahan juga memperluas kapasitas peserta didik untuk memahami budaya dan alam pikir asing. Penulis juga sudah menguraikan tahapan-tahapan melatihkan proses penerjemahan dalam ruang kelas Penulisan Akademis, baik secara normatif deskriptif maupun demonstratif sejauh menyangkut hasil-hasilnya yang teramati dan terukur. Pada bagian terakhir makalah, penulis juga sudah menyampaikan beberapa poin evaluasi terkait dengan isu penerjemahan berbasis teknologi, baik dilihat sebagai berkat, maupun dipersepsi sebagai kutuk (jika tidak diantisipasi), yang intinya adalah bahwa penerjemahan tidak bisa dilepaskan dari proses yang lebih besar dan luhur bernama 'humanisasi'.

Adapun tiga butir rekomendasi yang dapat penulis sampaikan pada bagian terakhir makalah ini adalah sebagai berikut. Pertama, melatih keterampilan penerjemahan untuk peserta didik di semua tingkat pendidikan formal bisa disampaikan dengan cara-cara yang lebih menarik, misalnya dengan bermain (kartu berisikan kutipan-kutipan inspiratif, misalnya) atau dengan penggunaan audio visual (contoh: film dengan subtitle-nya). Kedua, peran aktif dosen pengampu yang memperkenalkan 'penerjemahan' dalam perkuliahan adalah pertama-tama dengan memberikan teladan sebagai seorang 'penerjemah yang memang kompeten,' yang dibuktikan dengan 
menunjukkan hasil karya terjemahannya sehingga para siswa benar-benar memiliki role-model yang dekat yang dapat mereka tiru dan acu. Ketiga, penggunaan teknologi dalam bentuk MT bukanlah musuh yang harus dijauhi dalam pembelajaran penerjemahan di ruang kelas, melainkan alat bantu yang perlu diakrabi sejauh tersedia (dan lembaga pendidikan perlu memastikan agar akses internet bisa berjalan lancar ketika para peserta didik butuh menggunakannya!), tanpa mengkesampingkan baik asumsi maupun daya kritis para peserta didik (yang perlu terus dijaga dan diingatkan oleh dosen ketika proses menerjemahkan berlangsung) ketika mengevaluasi hasil terjemahan versi mesin atau MT (yang belum tentu akurat serta memuaskan).

\section{Daftar Pustaka}

Aiken, M. dan Balan, S. 2011. "An Analysis of Google Translate Accuracy" dalam Translation Journal, Volume 16, No. 2, April 2011, hlm. 1-5. Artikel bisa diakses di http://translationjournal.net/journal/56google.htm

Albir, A. H. dan Alves, F. 2009. "Translation as a cognitive activity" dalam Munday, J. Editor. The Routledge Companion to Translation Studies. London dan New York: Routledge.

Albir, A. H. 2010. "Competence" dalam Handbook of Translation Studies. Ed. Gambier, Y; van Doorslaer, L. Amsterdam: John Benjamins, hlm. 55-60.

Baker, M. 2011. In Other Words: A Coursebook on Translation. Second Edition. London: Routledge.

Dagilienè, I. 2012. "Translation as a Learning Method in English Language Teaching" dalam Jurnal Studies about Languages, No. 21, hlm. 124-129. Artikel bisa diakses di pranala http://dx.doi.org/10.5755/j01.sal.0.21.1469 atau pranala http://www.kalbos.ktu.lt/index.php/KStud/article/view/1469

Emzir. 2015. Teori dan Pengajaran Penerjemahan. Jakarta: PT Raja Grafindo Persada

Gerding-Salas, C. 2000. "Teaching Translation: Problems and Solutions" dalam Translation Journal, Vol. 4, No. 3, yang bisa diakses di pranala http://translationjournal.net/journal/13educ.htm

Hurst, M. 2007. Bit Literacy: Productivity in the Age of Information and E-mail Overload. New York: Good Experience Press

Jakobson, R. 1959. On Linguistic Aspects of Translation. Teks penuh bisa diakses di http://culturalstudiesnow.blogspot.co.id/2011/10/roman-jakobson-on-linguisticaspects-of.html

Kelly, D. 2005. A Handbook for Translator Trainers, Translation Practices Explained Series. Manchester: St. Jerome Publishers. 
Kovak, B. dan Rosenstiel, T. 2010. Blur: How to Know What's True in the Age of Information Overload. New York: Bloomsbury USA

Kuhiwczak, P. dan Littau, K. Tim Editor. 2007. A Companion to Translation Studies. Clevedon, Buffalo, Toronto: Multilingual Matters Ltd.

Kuntarto, Niknik M. dan Putranto, Hendar. 2015. 99 Cara Mudah Menulis Karya Ilmiah. Yogyakarta: Indo Publika

Leonardi, V. 2011. "Pedagogical Translation as a Naturally-Occurring Cognitive and Linguistic Activity in Foreign Language Learning" dalam jurnal Annali Online di Lettere - Ferrara, Vol. 1-2 (2011), hlm. 17-28.

Munday, J. Editor. 2009. The Routledge Companion to Translation Studies. Revised Edition. London dan New York: Routledge.

Newmark, P. 1988. A Textbook of Translation. New York, dll: Prentice Hall.

Pecorari, D. 2008. Academic Writing and Plagiarism: A linguistic analysis. London dan New York: Continuum

Pym, A. 2004. The Moving Text: Localization, translation, and distribution. Amsterdam/Philadelphia: John Benjamins Publishing Company.

---. 2011. "What technology does to translating" dalam jurnal The International Journal for Translation \& Interpreting Research, Vol 3, No 1, hlm. 1-9. Artikel bisa diakses di http://trans-int.org/index.php/transint/article/viewFile/121/81.

---. 2012. "Translation skill-sets in a machine-translation age," hlm. 1-17. Artikel bisa diakses di pranala http://usuaris.tinet.cat/apym/online/training/2012_competence_pym.pdf

Raído, V. E. 2014. Translation and Web Searching. New York dan London: Routledge.

Shreve, G. M. 2006. "The Deliberate Practice: Translation and Expertise" dalam Journal of Translation Studies, Vol. 9(1), hlm. 27-42. Artikel bisa diakses di http://traserver.tra.cuhk.edu.hk/index.php?option=com_content\&view=article\&i $\underline{\mathrm{d}=162 \& \text { Itemid }=681 \# \text { LINK002 }}$

Somers, H. Editor. 2003. Computers and Translation. Amsterdam/Philadelphia: John Benjamins Publishing Company.

Wilks, Y. 2009. Machine Translation: Its Scope and Limits. New York: Springer. 